\title{
Mapping the Intellectual Structure of Human Resource Management Studies: 1996-2005
}

\author{
Zhenzhong Ma \\ University of Windsor \\ E-Mail:maz@uwindsor.ca \\ Kuo-Hsun $\mathrm{Yu}$ \\ Chang Jung Christian University \\ E-Mail: yujacky@cc.feu.edu.tw \\ Yender Lee \\ Chang Jung Christian University \\ E-Mail: yender_lee@hotmail.com \\ Yuan-Duen Lee \\ Chang Jung Christian University \\ E-Mail: ydlee@mail.cjcu.edu.tw
}

\begin{abstract}
To map the intellectual structure of human resource management studies in the past decade, this study investigated the most important publications and the most influential scholars as well as the correlations among these documents by analyzing 33,132 citations of 1,267 articles published by SSCI journals in human resource management area between 1996 and 2005. This study further mapped the invisible network of knowledge of human resource management using co-citation analysis. Such a mapping can help identify the paradigm shift of human resource management research, and provide a valuable tool for researchers to access the literature in this area.
\end{abstract}

Keywords: Human Resource Management, Invisible Network of Knowledge, Citation and Co-citation Analysis, Mapping, Intellectual Structure 


\section{INTRODUCTION}

The past decade has seen active research in human resource management and thus produced an impressive array of literature of human resource management. While research findings in human resource management can be disseminated to scientists and practitioners in the form of journal articles, papers, books, and other documents, scholars are easily confused with the research subjects and their contributions to the development of human resource management when faced with thousands of human resource management publications. Great efforts have been made to explore these issues, yet all the issues are usually discussed solely based on experts' subjective assessment, which often leads to many controversies in the study of human resource management area.

To approach these issues in a more objective manner, a generic model of invisible network of knowledge (INK) is proposed in this paper which can be used to map the intellectual structure in the human resource management area. With citation and co-citation analysis this model is able to explore the intellectual structure of any existent field, delineate its knowledge network, and further portrait its knowledge diffusion process. The invisible network of knowledge (INK) model is defined in this paper as a set of interlinked invisible nodes, represented by different publications with their frequency of citations, and the correlations of these publications. Each set of such nodes serves a specific purpose for the study of human resource management or any other field of interest.

Following Latour's study (1987), this study uses epistemological scientometrics to portray the invisible network of knowledge in human resource management in order to identify the intellectual architects (who), the contributions of these intellectual architects (what), and the time and place in which they published them (when and where) in human resource management area. The purpose of this study is to map the intellectual structure of human resource management studies for the past decade between 1996 and 2005 and to explore the paradigm shifts of the invisible network of knowledge generation in the field of human resource management (Kuhn, 1962; 1963). The results of this study will also help those who want to independently study the related fields of human resource management. 


\section{THE THEORY OF THE INVISIBLE NETWORK OF KNOWLEDGE}

\section{The Concept of Knowledge}

Knowledge is the output of learning and knowing process, just as plans are the output of the planning process. Gibbons and colleagues (1994) contend that the terms of science and knowledge are often used interchangeably to form scientific knowledge. In his book, Science in Action, Latour (1987) defined the knowledge in term of familiarity and argued that a novice should become familiar with the intended knowledge generation or production system of a given field in order to understand the nature, its potential uses, and the evolutionary process in this field over time.

\section{The Concept of Network}

Networks have long been used in engineering and science for managing complex systems. In engineering and sciences, the word network commonly refers to a system or a web of inter-linked sub-systems or components, each of which is optimally designed to perform a designated task effectively. Each sub-system is highly specialized, and generally draws on high levels of accumulated knowledge and expertise within its expected domain of operations. By optimal inter-linking of these components, engineers and scientists achieve a much broader, and more complex, range of functions and capabilities than the reach of individual components or sub-systems. In a strict theoretical sense, the system as a whole may not be truly optimal, yet it can be effective and flexible enough to perform the task at hand, well beyond the summed capabilities of its individual parts. The two important components of network are key nodes and linkages whereby key nodes point out the system resources for knowledge generation with their connections by way of linkages.

\section{The Concept of Invisible College}

The concept of invisible colleges in academics can be traced back to Derek Price's (1963) proposal. Price defines the concept of research networks in that scholars working in the same area of research are linked together in invisible colleges through such informal ties as telephone calls, conversations at professional meetings, and preprint distribution. Nicholas Mullins (1972) also confirmed Prices’ view: researchers do claim to be stimulated relatively small groups of colleagues working on the same issues and building on each other's work. Wolek and Sanchez (1993) proposed that invisible college 
can be beneficial to a researcher to 1) identify specific colleagues working on the same or related topic; 2) learn what these colleagues know and are asking by communicating with them either through the literature or interpersonally; and 3) develop answers to these questions and communicate views via professional media.

\section{The Concept of Invisible Network of Knowledge (INK)}

Knowledge is complex and it is invisible. Consequently, it is very difficult for those who attempt to obtain knowledge because people have their own views concerning knowledge, which often results in misunderstanding about what is the knowledge add where the knowledge is residing. As a result, there's a strong need for an effective approach to helping people visualize knowledge, and further maintain and develop a common visualization and representation of knowledge. Chandy and William (1994) argue that every localized knowledge network is a part or sub-system of a broader and more general system. From that perspective, the knowledge network of one discipline could be viewed as an offshoot of its interacting foundational domains which are well-established sub-systems.

Adam Smith's “Invisible hand” reflects our appreciation of the elegant and smooth functioning of the market system as a coordinator of autonomous individual choices in an interdependent world. In a similar vein, because the development and diffusion of knowledge of one discipline can be formulated and changed by the nature and objective of relevant journals (especially those famous and major journals in this discipline), one discipline's journals can be regarded as an "invisible hand" to influence the locus of development and diffusion of the knowledge network of one given field.

Combining the concept of invisible college, the concept of invisible hand of journals, and the concept of knowledge seen as citation networks of scientific papers as most important scientists' communications (Price, 1965), we created a concept of Invisible Network of Knowledge production of a discipline (an INK model) for this study in order to help make the invisible more visible. With the help of INK model, the process from knowing nothing to knowing something is obviously more cost-effective, especially with the computer-aided data mining (Kuhn, 1962). In addition to the advantages of the traditional concept of knowledge network, INK model focuses more on the effect of invisible knowledge on a discipline (or a field) to make the invisible more visible by computer-aided epistemology. INK model can help map the knowledge network of a field (or a discipline) and reveal its locus of theory development and evolutionary trends. 
The invisible network of knowledge (INK) model would be an effective meta-method to represent invisible knowledge of a field. An invisible network of a field in nature can be viewed as the repository of broad and complex sets of expertise, experience, and accumulated theoretical essentials in its various parts of knowledge, from which both inside and outside members can draw for helping advance and refine this field.

\section{How Does the INK of Human Resource Management Develop?}

An invisible network of knowledge of any given field embodies both the knowledge content of its nodes and the inter-linkages of those nodes within its domain and to other fields. It can be viewed as the organized and the de-facto mirror of a field. The invisible network of knowledge of human resource management could be viewed as an offshoot of its interacting foundational domains which are well-established sub-systems of human resource management (i.e. publications relevant to human resource management). Even though these constituent or foundational fields may not contain sufficient concepts, ideas, frameworks, or relevant theoretical essentials to provide adequate solutions for the emerging problems facing the field of human resource management, they create a conducive environment for the cross fertilization of the relevant parts of constituent fields. The process of consolidation will further energize the fledging network to develop further richness to deal with higher complexity than before through the development of more powerful and stronger linkages (Ma, 2005). With more cross-cutting linkages formed among key nodes in the invisible network of knowledge, the new field becomes more integrated and more independent from its constituent domains and the field of human resource management develops and matures.

The landscape of a mature knowledge network in the human resource management field consists of a sufficiently large number of published articles, a great number of active researchers (the intellectual architects), and a large number of citations appearing in various media of the field of human resource management and elsewhere. In the following sections, we will be picturing the image of this invisible network, i.e., a collection of interconnected knowledge resources in terms of the intellectual, conceptual, or theoretical linkages, which is capable of portraying the developmental and diffusion patterns and processes in the knowledge system of human resource management area.

\section{RESEARCH METHODOLOGY AND RESULTS}

Based on the proposed INK model, the authors explored the intellectual structure of 
human resource management studies over the past decade between 1996 and 2005. This study chose this time period because the human resource management studies of the past decade represent the most important and the most updated research in human resource management area. Future analysis could take a longer period in order to have a longitudinal evolving picture in this area.

Citation and co-citation analysis is the main method for this study. With citation and co-citation analysis, this research assumed 3 phases, each of which required different approaches to examining the evolution of the human resource management studies. First, the databases were identified as the sources of human resource management publications. Then data collection and analysis techniques were designed to collect the desired information about the topics, authors, and journals on human resource management research.

In the second phase, the collected data were analyzed and systematized by sorting, summing, sub-totaling, ranking, and screening. After a series of operations, key nodes in the invisible network of knowledge in human resource management studies were identified and the structures developed. In the final stage, the knowledge network of human resource management was mapped to describe the knowledge distribution process in human resource management area. The objective of the third stage research was to project the future research directions by exploring the change pattern of star scholars or documents that have the most influence.

\section{Identification of Databases}

For the data presented here, the Social Science Citation Index (SSCI) was used as parts of the databases. The SSCI was widely used databases, which included citations published in about 2000 refereed journals. Using SSCI provided the most comprehensive and widely accepted databases of human resource management publications.

Unlike other prior studies, data used in this study were not drawn from journals chosen by the peer human resource management researchers (Holsapple, Johnson, Manakyan and Tanner, 1993; Walstrom and Leonard, 2000). Instead, the entire databases of SSCI from 1996 to 2005 served as the universe for conducting the analysis. Among the journals included in SSCI, the Human Resource Management (HRM), the International Journal of Human Resource Management (IJHRM), the International Journal of Manpower (IJM), and the International Journal of Selection and Assessment (IJSA) are arguably the most influential journals publishing human resource management 
related papers and are thus used as the core sources for analysis. The advantage of choosing these journals is the "guaranteed quality" of their published papers and their clear boundaries of what are the acceptable methods and topics of the field as defined by the editorial policies of the specific journals. Moreover, using SSCI as the universe for the citation data collected in this study were also less subject to flaws in personal judgment of the academic merits of various publications.

\section{Data Collection and Analysis}

Citation data was first collected from the journals by counting the number of articles published in these journals and the references these articles cited between 1996 and 2005. Over the 10 years, these journals published 1267 journal articles which cited 33132 other publications as referenced in these articles. The cited publications in these papers include both published books and other journal articles.

The most influential articles with the most citation and the most influential scholars were then identified by their total counts of citation within the selected journals. Among all the cited journal articles, the most cited human resource management article between 1996 and 2005 was Mark Huselid's paper (1995) The Impact of Human Resource Management Practices on Turnover, Productivity, and Corporate Financial Performance, followed by John Hunter and Ronda Hunter's paper (1984) Validity and Utility of Alternative Predictors of Job Performance, and Murray Barrick and Michael Mount's paper (1991) The Big Five Personality Dimensions and Job Performance: A Meta-analysis (see Table 1). Among all the cited books on the human resource management, the most cited one between 1996 and 2005 was Gert Hofstede' book (1980) Culture's Consequence: Comparing Values, Behaviors, Institutions and Organizations across Nations, followed by Dave Ulrich' book (1997) Human Resource Champions: The Next Agenda for Adding Value and Delivering Results, and John Hunter's methodology book (1990) Method of Meta-Analysis: Correcting Error and Bias in Research Findings (See Table 2). Journal articles and books combined, the most cited scholar between 1996 and 2000 (the five years) was John Hunter, followed by Dave Ulrich and Gert Hofstede (See Table 3). For the second five years, this picture changed dramatically. The most cited scholar between 2001 and 2005 was David Chan, followed by Stephen Gilliland and Sara Rynes (See Table 4). These scholars have the most influence in the development in the human resource management area and thus collectively define this field. 
Table 1 Top 15 Highly Cited Journal Articles in HRM Studies: 1996-2005

\begin{tabular}{|l|l|c|l|}
\hline FQ & \multicolumn{1}{|c|}{ Author } & Year & \multicolumn{1}{|c|}{ Full Article Title } \\
\hline 42 & Huselid-MA & 1995 & $\begin{array}{l}\text { The Impact of Human Resource Management Practices on Turnover, } \\
\text { Productivity, and Corporate Financial Performance }\end{array}$ \\
\hline 41 & Hunter-JE & 1984 & Validity and Utility of Alternative Predictors of Job Performance \\
\hline 39 & Barrick -MR & 1991 & $\begin{array}{l}\text { The Big Five Personality Dimensions and Job Performance: A } \\
\text { Meta-analysis }\end{array}$ \\
\hline 36 & Gilliland-SW & 1993 & $\begin{array}{l}\text { The Perceived Fairness of Selection Systems: An Organizational } \\
\text { Justice Perspective }\end{array}$ \\
\hline 32 & Schmidt-FL & 1998 & $\begin{array}{l}\text { The Validity and Utility of Selection Methods in Personnel } \\
\text { Psychology: Practical and Theoretical Implications of 85 Years } \\
\text { Research Findings }\end{array}$ \\
\hline 29 & Smither-JW & 1993 & Applicant Reactions to Selection Procedures \\
\hline 25 & Barney-J & 1991 & Firm resources and Sustained Competitive Advantage \\
\hline 23 & Ryan-AM & 2000 & $\begin{array}{l}\text { Applicants' Perception of Selection Procedures and Decision: A } \\
\text { Critical Review and Agenda for The Future }\end{array}$ \\
\hline 21 & Gilliland-SW & 1994 & $\begin{array}{l}\text { Effects of Procedure and Distributive Justice on Reactions to A } \\
\text { Selection System }\end{array}$ \\
\hline 20 & Arthur-JB & 1994 & $\begin{array}{l}\text { Effects of Human Resource Systems on Manufacturing Performance } \\
\text { and Turnover }\end{array}$ \\
\hline 20 & Baron-RM & 1986 & $\begin{array}{l}\text { The Moderator-Mediator Variable Distinction in Social Psychological } \\
\text { Research: Conceptual, Strategic, and Statistical Considerations }\end{array}$ \\
\hline 20 & Macan-TH & 1994 & $\begin{array}{l}\text { The Effects of Applicants' Reactions to Cognitive Ability Tests and an } \\
\text { Assessment Center }\end{array}$ \\
\hline 20 & Rynes-SL & 1993 & Applicant Reactions to Alternative Selection Procedures \\
\hline 19 & Arvey-RD & 1990 & Motivational Components of Test Taking \\
\hline Delery-JE & 1996 & $\begin{array}{l}\text { Modes of Theorizing in Strategic Human Resource Management : Tests } \\
\text { of Universalistic, Contingency, and Configurational Performance } \\
\text { Predictions }\end{array}$ \\
\hline
\end{tabular}




\section{Mapping the Invisible Network of Knowledge Production}

In this stage, data mapping was conducted and an intellectual structure of the human resource management studies was revealed by using co-citation analysis. Co-citation analysis is a bibliometric technique that information scientists use to map the intellectual structure of a research field. It involves counting documents from a chosen field - paired or co-cited documents. Co-citation studies compile co-citation counts in matrix form and statistically scale them to capture a snapshot at a distinct point in time of what is actually a changing and evolving structure of knowledge (Small, 1993).

Table 2 Top 15 Highly Cited Books in HRM Studies: 1996-2005

\begin{tabular}{|l|l|l|l|}
\hline FQ & \multicolumn{1}{|c|}{ Author } & Year & \multicolumn{1}{|c|}{ Full Article Title } \\
\hline 38 & Hofstede-G & 1980 & Culture's Consequences \\
\hline 23 & Ulrich-D & 1997 & Human Resource Champions \\
\hline 16 & Hunter-JE & 1990 & Method of Meta-Analysis \\
\hline 15 & Pfeffer-J & 1994 & $\begin{array}{l}\text { Competitive Advantage Through People: Unleashing the Power of the } \\
\text { Work Force }\end{array}$ \\
\hline 14 & Barber-AE & 1998 & Recruiting Employees: Individual and Organizational Perspectives \\
\hline 14 & Cohen-J & 1983 & Applied Multiple Regression \\
\hline 14 & Cohen-J & 1988 & Statistical Power Analysis for Behavior Sciences \\
\hline 14 & Mowday-RT & 1982 & $\begin{array}{l}\text { Employee-Organization Linkages: The Psychology of Commitment, } \\
\text { Absenteeism, and Turnover }\end{array}$ \\
\hline 14 & Murphy-KR & 1995 & $\begin{array}{l}\text { Understanding Performance Appraisal: Social, Organization, and } \\
\text { Goal-based Perspectives }\end{array}$ \\
\hline 13 & Vroom-VH & 1964 & Work and Motivation \\
\hline 12 & Mincer-J & 1974 & Schooling, Experience, and Earnings \\
\hline 12 & Nunnally-JC & 1978 & Psychometric Theory \\
\hline 12 & Ones-DS & 1993 & The Construct Validity of Integrity Tests \\
\hline 10 & Guion-RM & 1998 & Assessment, Measurement, and Prediction for Personnel Decisions \\
\hline 10 & Jensen-AR & 1980 & Bias in Mental Testing \\
\hline
\end{tabular}

Based on the total number of citations in the selected journals, the top 30 scholars were identified, and then a co-citation matrix was built before a pictorial map was drawn to describe the correlations among different publications. Because the SSCI only allow the co-citation analysis based on the total citations in the whole database, that is, the total 
number of citations within SSCI, not just the number of citations from the selected journals, the number of total citations used in Figure 1 and 2 were different from the ones listed in the tables. The publication associated with each author in Figure 1 and 2 was their representative publication.

Figure 1 clearly indicated that the most influential scholars in the human resource management studies between 1996 and 2000 clustered together, and thus formed the intellectual pillars in human resource management research. One cluster is about human resource and sustainable competitive advantage, where Barney (1991) and Pfeffer (1994) were jointly defining this area. Another cluster is about effects of human resource systems on manufacturing performance as well as on the turnover rate, where Arthur (1994), Huselid (1995), and MacDuffie (1995) made great contributions and thus were highly co-cited in the human resource management studies. Barrick and Mount (1991) and Hunter and Hunter (1984) formed another cluster where the topic was about personality dimensions and other predictors of job performance. Another less complex cluster, Wright and McMahan (1992), defined Strategic Human Resource Management, and thus was correlated with many other scholars. These different clusters formed the intellectual structure in human resource management studies.

More specifically, Barney (1991) first addressed the resource-based view of firm competitive advantage and four empirical indicators of the potential of firm resource to generate sustained competitive advantage - value, rareness, limitability, and substitutability. Pfeffer (1994) submitted that it is essential to care about people and their lives and well-being, and successful firms understand the message of gaining competitive through people. Wright and McMahan (1992) defined strategic human resource management (SHRM) as the pattern of planned human resource deployments and activities intended to enable an organization to achieve its objective. SHRM studies focused on explicating the strategic role that human resource can play in organizational functioning. Much of SHRM research focused on establishing a link between strategic human resource policies and practices and organizational level measures of performance. As part of this latter perspective, human resource systems are view as an integral part of the organizational 'architecture' that influences organizational effectiveness. Unlike traditional research in the human resource literature, SHRM research was typically conducted at business unit or organizational level. Reflecting this orientation, recent human resource management research focused on 'bundles' or systems of human resource policies and practices to promote skills, commitment, and performance so that 
employees became a source of sustainable organizational success (Levine,1995; Pfeffer, 1998). With SHRM gaining its central status in the human resource management area, scholars began to explore the linkage between human resource practices, organizational performance, and company's competitive ability. Many researchers (Arthur, 1994; Becker \& Gerhart, 1996; Huselid, 1995; Youndt et al., 1996) produced evidence of the value of progressive human resource practices and systems on company outcomes. Other studies found that there was a positive association between human-capital-enhancing human resource management and organizational outcomes (Cascio, 1991; Delaney \& Huselid, 1996; Flamholtz, 1985; Huselid, 1995; Youndt et al., 1996). In industrial settings, SHRM studies empirically linked human resource management systems with turnover (e.g., Arthur, 1994), productivity (e.g. Arthur, 1994; Koch \& McGrath, 1996; MacDuffie, 1995), and product/service quality (e.g., MacDuffie, 1995; Youndt et al., 1996), as shown in the topics of other research clusters in Figure 1.

Table 3 Top 10 Highly Cited Scholars in HRM Area and Their Representative Publications: 1996-2000

\begin{tabular}{|c|c|c|c|c|c|c|}
\hline \multirow{2}{*}{\begin{tabular}{|l}
$\begin{array}{l}\text { Total } \\
\text { Cited }\end{array}$ \\
\end{tabular}} & \multirow{2}{*}{ Author } & \multirow{2}{*}{ Contributions } & \multicolumn{4}{|c|}{ Representative Publication } \\
\hline & & & \multicolumn{4}{|c|}{ (Frequency/Type/Year/ Full Citation Index) } \\
\hline 31 & HUNTER-JE & 2 & 24 & $\mathrm{~J}$ & $\left.1984\right|_{\mathrm{H}} ^{\mathrm{H}}$ & $\begin{array}{l}\text { HUNTER JE, 1984, PSYCHOL } \\
\text { BULL, V96, P72 }\end{array}$ \\
\hline 24 & ULRICH-D & 3 & 11 & B & $\left.1997\right|_{\mathrm{H}} ^{\mathrm{L}}$ & $\begin{array}{l}\text { ULRICH D, 1997, HUMAN } \\
\text { RESOURCE CHAMP }\end{array}$ \\
\hline 23 & HOFSTEDE-G & 2 & 18 & B & 1980 & $\begin{array}{l}\text { HOFSTEDE G, 1980, CULTURES } \\
\text { CONSEQUENCE }\end{array}$ \\
\hline 22 & SHACKLETON-V & 2 & 11 & $\mathrm{~J}$ & 1994 & $\begin{array}{l}\text { SHACKLETON V, 1994, INT J } \\
\text { SELECT ASSESS, V2, P91 }\end{array}$ \\
\hline 17 & BANDURA-A & 3 & 7 & B & $1986 \frac{\mathrm{H}}{\mathrm{T}}$ & $\begin{array}{l}\text { BANDURA A, 1986, SOCIAL F } \\
\text { THOUGHT ACT }\end{array}$ \\
\hline 17 & LOUIS-MR & 2 & 11 & $\mathrm{~J}$ & $1980 \frac{1}{1}$ & $\begin{array}{l}\text { LOUIS MR, 1980, ADM SCI Q, V25, } \\
\text { P226 }\end{array}$ \\
\hline 16 & GILLILAND-SW & 2 & 10 & $\mathrm{~J}$ & $\left.1993\right|_{1} ^{2}$ & $\begin{array}{l}\text { GILLILAND SW, 1993, ACAD } \\
\text { MANAGE REV, V18, P694 }\end{array}$ \\
\hline 15 & ARVEY-RD & 3 & 6 & $\mathrm{~J}$ & 1982 & $\begin{array}{l}\text { ARVEY RD, 1982, PERS PSYCHOL, } \\
\text { V35, P281 }\end{array}$ \\
\hline 15 & HUSELID-MA & 1 & 15 & $\mathrm{~J}$ & $\left.1995\right|_{1} ^{\mathrm{H}}$ & $\begin{array}{l}\text { HUSELID MA, 1995, ACAD } \\
\text { MANAGE J, V38, P635 }\end{array}$ \\
\hline 15 & SCHULER-RS & 3 & 6 & $\mathrm{~J}$ & 1987 & $\begin{array}{l}\text { SCHULER RS, 1987, ACADEMY } \\
\text { MANAGEMENT E, V1 }\end{array}$ \\
\hline
\end{tabular}


Table 4 Top 10 Highly Cited Scholars in HRM Area and Their Representative Publications: 2001-2005

\begin{tabular}{|c|l|c|c|c|c|l|}
\hline \multirow{2}{*}{$\begin{array}{l}\text { Total } \\
\text { Cited }\end{array}$} & \multicolumn{1}{|c|}{ Author } & \multirow{2}{*}{ Contributions } & \multicolumn{4}{|c|}{ Representative Publication } \\
\cline { 5 - 7 } & CHAN-D & 5 & 15 & $\mathrm{~J}$ & 1997 & $\begin{array}{l}\text { CHAN D, 1997, J APPL PSYCHOL, } \\
\text { V82, P300 }\end{array}$ \\
\hline 50 & GILLILAND-SW & 3 & 26 & $\mathrm{~J}$ & 1993 & $\begin{array}{l}\text { GILLILAND SW, 1993, ACAD } \\
\text { MANAGE REV, V18, P694 }\end{array}$ \\
\hline 49 & RYNES-SL & 6 & 14 & $\mathrm{~J}$ & 1993 & $\begin{array}{l}\text { RYNES SL, 1993, J BUSINESS } \\
\text { PSYCHOL, V7, P261 }\end{array}$ \\
\hline 42 & SCHMIDT-FL & 3 & 31 & $\mathrm{~J}$ & 1998 & $\begin{array}{l}\text { SCHMIDT FL, 1998, PSYCHOL } \\
\text { BULL, V124, P262 }\end{array}$ \\
\hline 40 & BARRICK-MR & 3 & 29 & $\mathrm{~J}$ & 1991 & $\begin{array}{l}\text { BARRICK MR, 1991, PERS } \\
\text { PSYCHOL, V44, P1 }\end{array}$ \\
\hline 36 & HUNTER-JE & 4 & 17 & $\mathrm{~J}$ & 1984 & $\begin{array}{l}\text { HUNTER JE, 1984, PSYCHOL } \\
\text { BULL, V96, P72 }\end{array}$ \\
\hline 36 & RYAN-AM & 3 & 23 & $\mathrm{~J}$ & 2000 & $\begin{array}{l}\text { RYAN AM, 2000, J MANAGE, } \\
\text { V26, P565 }\end{array}$ \\
\hline 33 & HUSELID-MA & 2 & 27 & $\mathrm{~J}$ & 1995 & $\begin{array}{l}\text { HUSELID MA, 1995, ACAD } \\
\text { MANAGE J, V38, P635 }\end{array}$ \\
\hline 33 & ONES-DS & 4 & 12 & $\mathrm{~B}$ & 1993 & ONES DS, 1993, J APPL PSYCHO \\
\hline 30 & PLOYHART-RE & 3 & 11 & $\mathrm{~J}$ & 1999 & $\begin{array}{l}\text { PLOYHART RE, 1999, J APPL } \\
\text { PSYCHOL, V84, P87 }\end{array}$ \\
\hline
\end{tabular}

Similarly, Figure 2 indicated that the major human resource management studies between 2001 and 2005 also clustered around several key research topics, and thus formed the intellectual structure in contemporary human resource management research. The appearance of more clusters in Figure 2 and the disappearance of the cluster represented by Wright and McMahan (1992) showed that a paradigm shift has occurred (Kuhn, 1962). Besides the traditional research stream on the impact of human resource system on turnover, productivity, and other organizational performance, as studied by the cluster consisting of Barney (1991), Becker and Gerhart (1996), and Huselide (1995), the human resource management studies have shifted their focus to other domains. The most coherent research cluster in the field is the relationship between personality and job performance. In a meta-analysis of research on various predictors of job performance, Hunter \& Hunter (1984) found general cognitive ability to be the most valuable predictor 
for entry-level jobs. Furthermore, the use of selection that is associated with high predictive validity can facilitate the detection of highly productive employees and the optimization of the person-job-organization fit. Meta-analytic studies and others (Barrick \& Mount, 1991; Tett et al., 1991; Salgado, 1997; Schmidt \& Hunter, 1998) suggested that personality traits, as measured by the "Big Five", have considerable utility for predicting how people behave and perform in the workplace. Evidence showed that specific personality traits are related in predictable ways to performance in certain kinds of jobs. Specifically, Barrick and Mount (1991) found that one dimension of personality, Conscientiousness, showed consistent relationships with all job performance criteria for all occupational groups. In a meta-analysis of the Big Five in the European Community, Salgado (1997) found that Conscientiousness and Emotional Stability are valid predictors across job criteria and occupational groups. Practically speaking, the last decade has witnessed a revolution in personnel selection largely due to the publication of the Big Five and its significant correlations with important job criteria (Barrick \& Mount, 1991; Salgado, 1997). From a different perspective, Hough (1992) demonstrated that when prediction of specific criteria is at stake, the Big Five may fail to provide the level of specificity required for understanding the personality effects on criteria such as specific attitudes and intentions, job performance and satisfaction, or multicultural success. In addition, Ones et al. (1993) suggested that conscientiousness appears to be the underlying factor in personality-based integrity tests.

Although the Big Five dimensions of personality became the main research stream in the human resource management studies, scholars proposed other prospects. For example, Schmidt \& Hunter (1998) found that cognitive ability is a typical predictor of both job and training performance; general mental ability is known to effectively influence and predict job performance. Also related to this topic, Borman \& Motowidlo (1997) differentiated behaviors of contextual performance and task performance in personnel selection and its meaning to personnel selection research. A relatively small cluster consisted of Cohen and Cohen (1983) and Hofstede (1980), both of whom are well-known statistics scholars and their appearance in the picture showed that research methodology in the human resource management studies is gaining momentum.

Other cluster of scholars focused their research on selection procedure. Many researches focused on the fairness perceptions of organizational decisions, collectively termed as distributive justice, and on the fairness perceptions of the processes used to make organizational decisions, known as procedural justice. Considerable progress has 
been made to a better understanding of the factors in such perceptions (Gilliand, 1993; Ryan \& Ployhart, 2000). Gilliland's (1993) justice model of applicant reactions to selection procedures suggested that applicants are liked to respond negatively. His model categorizes procedure justice rules into three broad categories: formal characteristics (i.e. job relatedness, consistence); explanation (i.e. feedback, information known); and interpersonal treatment (i.e. two-way communication, treatment at test site). Gilliland (1993) asserted that these rules influenced perception of fairness of the selection procedure, which, in turn, influenced applicant's perceptions of the organization. The positive relation between self-efficacy and performance had also been supported with respect to cognitive ability employment tests (Bauer et al., 1998; Ryan et al., 1998). In addition, Smither et al. (1993) pointed out that applicant reactions to selection led to the pursuit and acceptance of job offers through perceptions of attractiveness.

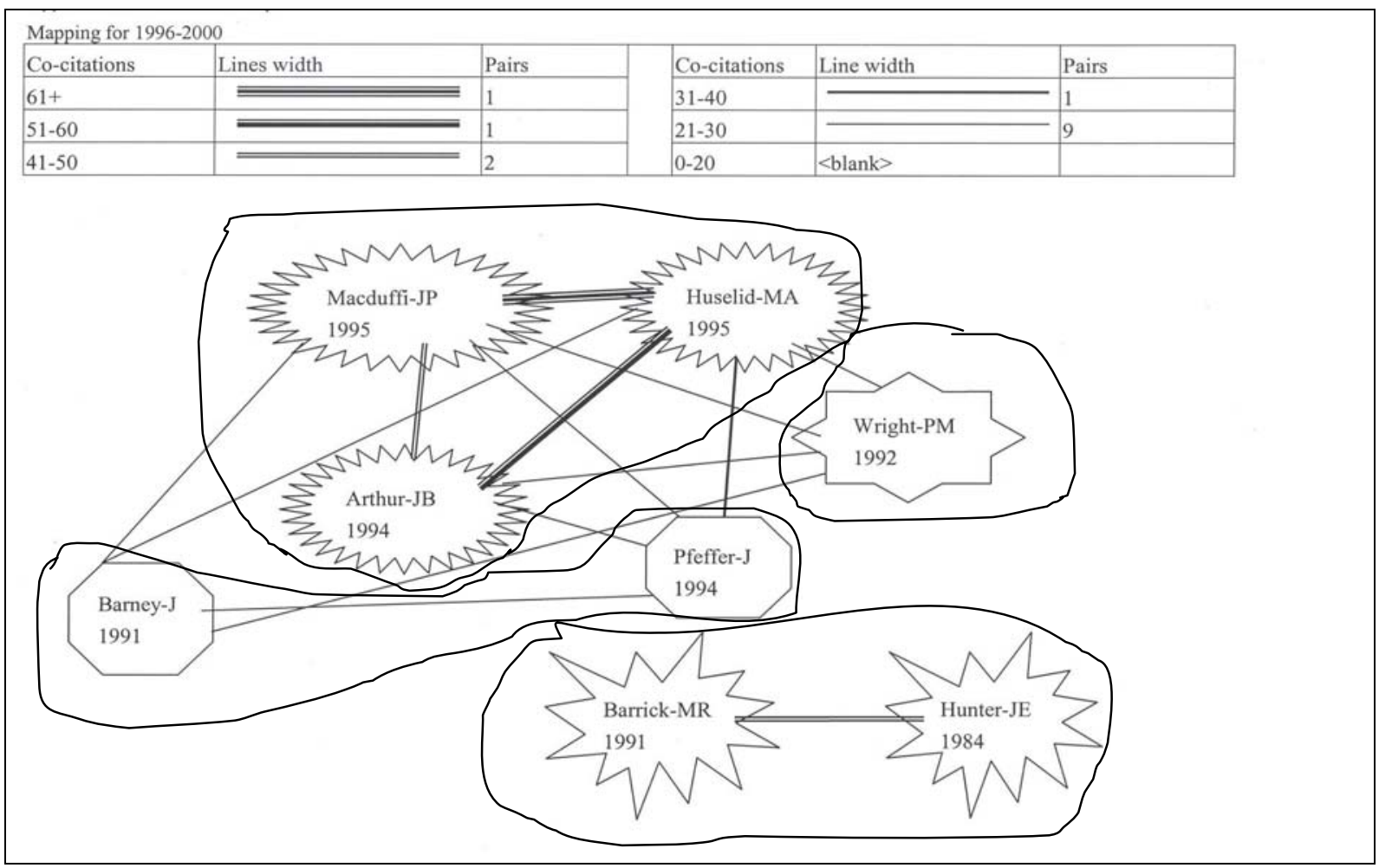

Figure 1 Co-Citation Mapping of the Human Resources Management Studies: 1996-2000 


\section{CONCLUSIONS}

The result of this study supports that fact that the studies of human resource management are experiencing a paradigm shift over time during the selected time period. The invisible network of human resource management during 1996-2000 shows the most influential nodes is strategic human resource management. When it comes to 2001-2005, the main picture of the invisible knowledge network has changed. The most influential nodes and their research field is the relationship between personality and job performance.

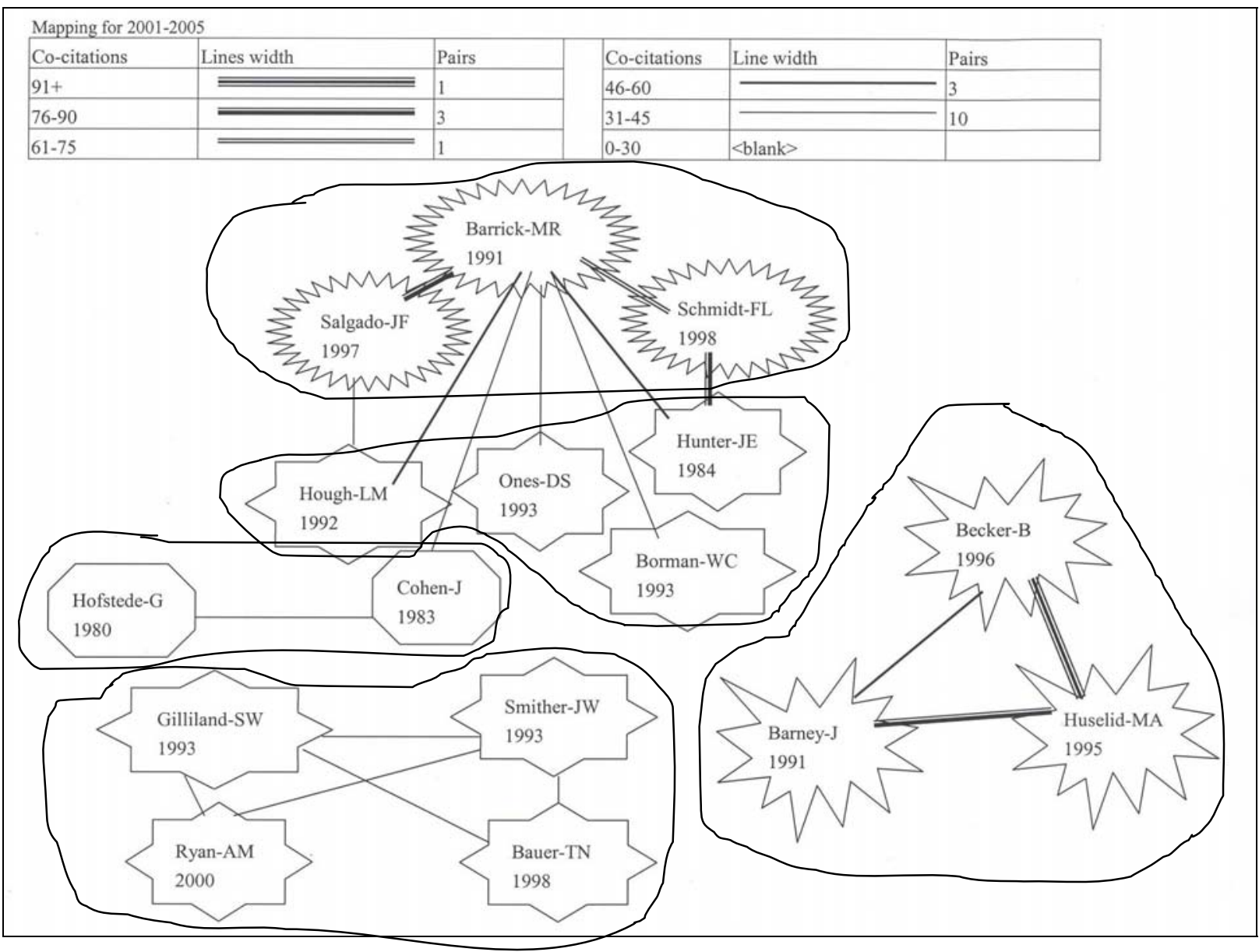

Figure 2 Co-Citation Mapping of the Human Resources Management Studies: 2001-2005

Using the human resource management studies between 1996 and 2005 collected in SSCI, this study demonstrates the application of the INK model in identifying the most 
influential scholars and publications that have defined the development and growth of the human resource management studies and further in mapping an intellectual structure in human resource management area. The mapping results clearly showed clusters research topics in different periods in the human resource management studies and reflected the shift in research paradigm. In addition, this model can help us obtain a better understanding of the concepts, ideas, frameworks, and theories of human resource management by tracing the research path and mapping the paradigm shift through the cited references. The development of such a model of the invisible network of knowledge production is an important step forward in systematizing the use of citation data for the study of human resource management research. Besides the importance of the intellectual structure of knowledge production of human resource management studies revealed in this paper by using the INK model, this model also has important implications for the epistemology of any scientific field.

\section{REFERENCES}

Arthur, J. B. (1994). Effects of Human Resource Systems on Manufacturing Performance and Turnover. Academy of Management Journal, 37(3), 670-687.

Barney, J. (1991). Firm resources and Sustained Competitive Advantage. Journal of Management, 17(1), 99-120.

Barrick, M. R. \& Mount, M. (1991). The Big Five Personality Dimensions and Job Performance: A Meta-analysis. Personnel Psychology, 44, 1-16.

Bauer, T. N., Maertz, Jr. C. P., Dolen, M. R., and Campion M. A. (1998). Longitudinal Assessment of Applicant Reactions to Employment Testing and Test Outcome Feedback. Journal of Applied Psychology, 83(6), 892-923.

Becker, B. E., \& Gerhart, B. (1996). The impact of Human Resource Management on Organizational Performance: Progress and Prospects. Academy of Management Journal, 39(4), 779-801.

Borman, W. C., \& Motowidlo, S. J. (1997). Task Performance and Contextual Performance: The Meaning for Personnel Selection Research. Human Performance, 10(2), 99-109.

Cascio, W. F. (1991). Costing Human Resource: The Financial Impact of Behavior in Organizations ( $3^{\text {rd }}$ ed.). Boston, MA: Pws-Kent.

Chandy, P. R. \& Williams, T. G. F. (1994). The Impact of Journals and Authors on International Business Research: a Citation Analysis of JIBS Articles. Journal of 
International Business Studies, 25(4), 715-728.

Cohen, J., \& Cohen, P. (1983). Applied multiple regression/correlation analysis for the behavioral sciences. Hillsdale, New Jersey: Erlbaum.

Delaney, J. T., and Huselid, M. A. (1996). The Impact of Human Resource Practices on Perceptions of Organizational Performance. Academy of Management Journal, 39(4), 949-969.

Flamholtz, E. G. (1985). Human Resource Accounting (2 ${ }^{\text {nd }}$ ed.). San Francisco, CA: Jossey-Bass.

Gibbons, M, Limorges, C, Nowwothy, H, Schwartzman, S, Scott, P., \& Trow, M. (1994). The New Production of Knowledge: the Dynamics of Science and Research in Contemporary Societies. London: Sage.

Gilliland, S. W. (1993). The Perceived Fairness of Selection Systems: An Organizational Justice Perspective. Academy Management of Review, 18(4), 694-734.

Gilliland, S. W. (1994). Effects of Procedure and Distributive Justice on Reactions to a Selection System. Journal of Applied Psychology, 79(5), 691-701.

Hofstede, G. (1980). Culture's Consequences: International Differences in Work-Related Values. Beverly Hills, CA: Sage.

Holsapple, C.W., Johnson, L.E., Manakyan, H., \& Tanner, J. (1993). A citation analysis of business computing research journals. Information \& Management, 25, 231-244.

Hough, L. M. (1992). The Big Five Personality Variables-Construct Confusion: Description versus Prediction. Human Performance, 5(1\&2), 139-155.

Hunter, J. E., \& Hunter, R. F. (1984). Validity and Utility of Alternate Predictors of Job Performance. Psychology Bulletin, 96(1), 72-98.

Hunter, J.E., \& Schmidt, F. L. (1990). Method of Meta-analysis: Correcting Error and Bias in Research Findings. Newbury Park, CA: Sage.

Huselid, M. A. (1995). The Impact of Human Resource Management Practices on Turnover, Productivity, and Corporate Financial Performance. Academy of Management Journal, 38(3), 635-672.

Koch, M. J., \& McGrath, R. G. (1996). Improving Labor Productivity: Human Resource Management Policies Do Matter. Strategic Management Journal, 17, 335-354.

Kuhn T. (1962). The Structure Of Scientific Revolutions. Chicago: University of Chicago Press.

Kuhn, T. (1963). The Function of Dogma in Scientific Research. In A. C. Crombie (Ed.), Scientific Change (pp.347-369). New York: Basic Books. 
Latour, B. (1987). Science in Action: How to Follow Scientists and Engineers through Society. Cambridge, MA: Harvard University Press.

Levine, D. (1995). Reinventing The Workplace: How Business and Employers Can both Win .Washington, DC: Brooking Institution.

Ma, Z. (2005). From theoretical essentials to paradigm: The development path of electronic commerce research. International Journal of Electronic Business, 3(5), 491-507.

MacDuffie, J. (1995). Human Resource Bundles and Manufacturing Performance: Organizational Logic and Flexible Production Systems in the World Auto Industry. Industrial and Labor Relations Review, 48(2), 197-221.

Mullins, N. (1972). The Development of a Scientific Specialty. Minerva, 10(1), 51-82.

Ones, D. S., Viswesvaran, C., and Schmidt, F. L. (1993). Comprehensive Meta-Analysis of Integrity Test Validities Findings and Implications for Personnel Selection and Theories of Job Performance. Journal of Applied Psychology, 78(4), 679-703.

Pfeffer, J. (1994).Competitive Advantage through People: Unleashing the Power of the Work Force. Boston, MA: Harvard Business School Press.

Pfeffer, J. (1998). The Human Equation: Building Profits by Putting People Firs. Boston, MA: Harvard Business School Press.

Price, D. (1963). Little Science, Big Science, and Beyond. New York: Columbia University Press.

Price, D. (1965). Networks of Scientific Papers. Science, 149, 510-515

Ryan, A. M., Ploychart, R. E., Greguras, G. J., and Schmit, M. J. (1998). Test Preparation Programs in Selection Contexts: Self-selection and Program Effectiveness. Personnel Psychology, 51, 599-621.

Ryan, A. M., \& Ploychart, R. E. (2000). Applicants' Perception of Selection Procedures and Decision: A Critical Review and Agenda for The Future. Journal of Management, 26(3), 565-606.

Salgado, J. F. (1997). The Five Factor Model of Personality and Job Performance in the European Community. Journal of Applied Psychology, 82(1), 30-43.

Schmidt, F. L., \& Hunter, J. E. (1998). The Validity and Utility of Selection Methods in Personnel Psychology: Practical and Theoretical Implications of 85 Years of Research Findings. Psychological Bulletin, 124(2), 262-274.

Small, H. G. (1993). Macro-level changes in the structure of co-citation clusters: 1983-1989. Scientometrics, 26, 5-20. 
Smither, J. W., Reilly, P. R., Millsap, R. E., Pearlman, K., \& Stoffey, R. W. (1993). Applicant Reactions to Selection Procedures. Personnel Psychology, 46(1), 49-77.

Tett, R., Jackson, D., \& Rothstein, M. (1991). Personality Measures as Predictors of Job Performance: A Meta-analysis Review. Personnel Psychology, 44(4), 703-742.

Ulrich, D. (1997). Human Resource Champions: The Next Agenda for Adding Value and Delivering Results. Harvard Business Press, Boston, MA.

Walstrom, K.A. \& Leonard, L. (2000). Citation classics from the information systems literature. Information \& Management, 38, 59-72.

Wolek, F. W., \& Sanchez, P. M. (1993). Research Administrators as "Invisible College” Facilitators. SRA Journal, 24(4), 27-34.

Wright, P. M., \& McMahan, G. C. (1992). Theoretical Perspectives for Strategic Human Resource Management. Journal of Management, 18(2), 295-320.

Youndt, M. A., Snell, S. A., Dean J. W., \& Lepak, D. P. (1996). Human Resource Management, Manufacturing Strategy, and Firm Performance. Academy of Management Journal, 39(4), 836-866. 
